\title{
Determinan Keberlanjutan Usahatani Padi Sawah Tadah Hujan: Kasus Desa Pesisir Kalimantan Barat
}

\author{
Ari Natul Hidayah, Jajat Sudrajat*, Wanti Fitrianti \\ Program Studi Agribisnis, Jurusan Sosial Ekonomi Pertanian, Fakultas Pertanian, Universitas Tanjungpura, Pontianak
}

\begin{abstract}
ABSTRAK
Usahatani padi di perdesaan Kalimantan Barat sedang menghadapi tekanan dari segi persaingan penggunaan lahan. Masalah ini bisa semakin meminggirkan kelompok rentan di perdesaan, ketidakamanan pangan, dan memperlebar kesenjangan sosial. Penelitian ini bertujuan untuk menganalisis indikator penentu keberlanjutan usahatani padi sawah tadah hujan di Desa Telaga Arum; sebuah desa pesisir yang berada dalam administrasi Kecamatan Seponti, Kabupaten Kayong Utara, Provinsi Kalimantan Barat. Studi ini menerapkan metode MICMAC (Matrix of Cross Impact Multiplications Applied to a Classification) sebagai alat analisisnya. Hasil studi menunjukkan bahwa keberlanjutan usahatani padi sangat dipengaruhi oleh indikator kehadiran komoditas kelapa sawit, iklim, dan kesuburan tanah. Ketiga indikator tersebut dapat menyebabkan gangguan terhadap sistem usahatani padi dalam jangka pendek dan jangka panjang. Ekspansi kebun kelapa sawit yang mencapai luasan rata-rata kurang lebih 1300 hektar per tahun, telah menjadi ancaman nyata terhadap areal persawahan terutama dalam lima tahun terakhir di Kabupaten Kayong Utara. Studi ini juga menemukan bahwa motivasi petani adalah aspek yang paling terpengaruh dalam perspektif jangka panjang dan cenderung mengalami kemunduran, karena motivasi usahatani padi hanya ditujukan untuk memenuhi kebutuhan subsisten.
\end{abstract}

Kata kunci: Usahatani padi, ketahanan pangan, keberlanjutan, motivasi petani, kelapa sawit

\begin{abstract}
Rice farming in rural West Kalimantan is facing pressure in terms of land-use competition. This problem can further marginalize the vulnerable groups in rural areas, food insecurity, and widen social inequality. This study aimed to analyze the determinants of the sustainability of rainfed rice farming in the village of Telaga Arum; a coastal village located in the subdistrict of Seponti, Kayong Utara regency, West Kalimantan. This study applies the MICMAC (Matrix of Cross Impact Multiplications Applied to a Classification) method as an analytical tool. The results of the study show that the sustainability of rice farming is strongly influenced by indicators of the presence of oil palm commodities, climate, and soil fertility. These three indicators can cause disturbances to the rice farming system in the short and long term. The oil palm expansions which reach an average area of roughly 1300 hectares per year has become a real threat to the rice fields especially in the last five years in Kayong Utara regency. This study also found the farmer's motivation is an aspect that is the most affected in the long term perspective and tends to decline because the rice farming motivation is only to fulfill subsistence needs.
\end{abstract}

Keywords: Rice farming, food security, sustainability, farmer motivation, oil palm

Citation: Hidayah, A.N., Sudrajat, J., dan Fitrianti, W. (2022). Determinan Keberlanjutan Usahatani Padi Sawah Tadah Hujan: Kasus Desa Pesisir Kalimantan Barat. Jurnal Ilmu Lingkungan, 20(2), 382-395, doi:10.14710/jil.20.2.382-395

\section{Latar Belakang}

Secara umum dalam dua dekade terakhir usahatani padi di Kalimantan Barat sedang menghadapi tekanan akibat adanya pergeseran penggunaan lahan. Hal ini tidak hanya terjadi di daerah pedalaman namun juga mencapai area pesisir. Persaingan penggunaan lahan semakin meningkat khususnya antara komoditas tanaman subsisten (padi) dan komoditas tujuan komersil. Tekanan ini mengakibatkan upaya peningkatan produktivitas padi atau bahkan keberlanjutannya mengalami gangguan. Makna berkelanjutan di sini diartikan sebagai upaya menjadikan usahatani dapat berlangsung terus- menerus dan produktif dengan tetap menjaga kelestarian sumber daya alam (Sudalmi, 2010).

Fenomena persaingan penggunaan lahan semakin dirasakan di wilayah pesisir yang teknologi budidayanya masih tradisional, seperti secara umum masih berorientasi pada penggunaan varietas padi lokal dan penggunaan input produksi lainnya yang belum optimal. Gejala seperti itu terjadi di Desa Telaga Arum, sebuah desa pesisir yang berada di Kecamatan Seponti, Kabupaten Kayong Utara, Provinsi Kalimantan Barat. Tanah sawah tadah hujan di daerah rawa pasang surut terus mengalami pengurangan karena pemanfaatannya beralih kepada komoditas perkebunan atau hortikultura. Pada sisi lain, perubahan penggunaan lahan juga akan semakin

\footnotetext{
*Penulis korespondensi: jajat.sudrajat@faperta.untan.ac.id
} 
meminggirkan kelompok-kelompok rentan di perdesaan yang sangat bergantung pada padi sebagai sumber ketahanan pangan mereka.

Persaingan penggunaan lahan dirasakan semakin meningkat akibat semakin meningkatnya perekonomian wilayah. Kompetisi ini tidak hanya sebatas berdampak pada ekonomi padi, namun juga pada kondisi lingkungan usahataninya. Misalnya, letak atau lokasi lahan usahatani padi tidak bisa berdampingan dengan kebun karet atau kelapa sawit. Selain menimbulkan masalah naungan yang mengurangi lama penyinaran matahari, juga dapat memicu meningkatnya populasi hama tikus, khususnya ketika berdampingan dengan kebun kelapa sawit (Widians \& Rizkyani, 2020). Tekanan seperti ini, sebagian besar terjadi pada area lahan rawa pasang surut pada tipe luapan $\mathrm{C}$ dan D atau dikatakan sebagai daerah persawahan tadah hujan di lingkungan pesisir.

Faktor lain adalah meningkatnya fenomena perubahan iklim yang diakibatkan semakin meningkatnya pemanasan global. Hal ini mengharuskan petani mengambil sikap dalam waktu tanam dan cara-cara bertaninya. Waktu tanam menentukan ketersediaan air, sedangkan cara-cara bertani berkaitan dengan pemupukan dan upaya menghindari genangan yang berlebihan. Berdasarkan aspek-aspek ini maka keberlanjutan usahatani padi semakin penting dalam era pembangunan pertanian saat ini, karena padi sebagai sumber ketahanan pangan (Asnawi et al., 2020).

Beberapa fenomena yang digambarkan di atas, selanjutnya memberi arah mengenai pentingnya mengetahui faktor-faktor yang menentukan keberlanjutan usahatani padi secara komprehensif, dalam perspektif jangka pendek maupun jangka panjang. Di Kalimantan Barat, hal ini menjadi penting karena terkait dengan perencanaan sebelumnya yang menetapkan daerah pesisir sebagai sumber pemenuhan pangan pokok, sebagaimana telah direncanakan sejak tahun 1970an dalam Proyek Pembukaan Persawahan Pasang Surut tahun 19691984 (Noor et al., 2014). Berkaitan dengan hal itu, secara spesifik penelitian ini bertujuan mengidentifikasi faktor-faktor penentu, tingkat pengaruh, dan ketergantungan antar indikator keberlanjutan usahatani padi sawah tadah hujan di daerah pesisir Kalimantan Barat.

\section{Metode Penelitian}

\subsection{Tempat dan Waktu Penelitian}

Fokus lokasi penelitian dilakukan di Desa Telaga Arum, Kecamatan Seponti, Kabupaten Kayong Utara, Provinsi Kalimatan Barat (Gambar 1). Pemilihan lokasi ditentukan secara sengaja (purposively) dengan pertimbangan bahwa desa ini sebagai desa pesisir yang dalam dekade terakhir sedang menghadapi tekanan penggunaan lahan untuk berbagai kemungkinan pilihan komoditas. Kegiatan penelitian ini dilaksanakan pada bulan April sampai dengan bulan Mei tahun 2021.

\subsection{Metode Pengumpulan Data}

Proses pengumpulan data dilakukan dengan dua cara. Pertama, melakukan wawancara semiterstruktur terhadap para petani untuk mengumpulkan data karakteristik petani, masalahmasalah yang ada saat ini, dan juga keterkaitan antara satu fenomena penggunaan lahan dan aspek-aspek lainnya. Instrumen wawancara menggunakan daftar pertanyaan (kuesioner). Responden sebanyak 33 petani ditentukan secara sengaja dengan mempertimbangkan kemampuan berkomunikasi, karakteristik petani, dan informasi yang ingin diperoleh. Kedua, menyelenggarakan FGD terhadap narasumber yang relevan, yaitu para pihak yang memahami masalah-masalah usahatani di level on farm maupun off farm. Narasumber dimaksud adalah aparat Dinas Pertanian dan Pangan Kabupaten Kayong Utara, aparat desa, penyuluh pertanian, perwakilan anggota kelompok tani, dan petani padi. Berdasarkan keterwakilan dari narasumber tersebut, FGD ini dihadiri oleh sebanyak 11 peserta. Selanjutnya, sumber data lainnya diperoleh dari observasi selama penelitian dan data sekunder dari Badan Pusat Statistik (BPS).

\subsection{Analisis Data}

Analisis data dalam penelitian ini menggunakan metode MICMAC (Matrix of Cross Impact Multiplications Applied to a Classification), yaitu metode khusus yang berhasil dikembangkan oleh Godet sekitar tahun 1994 (Fauzi, 2019). Analisis MICMAC ini merupakan pendekatan yang mengandalkan pemikiran analitis melalui pemecahan yang sistematis terhadap suatu permasalahan. Menurut Fauzi (2019), terdapat tiga tahapan dalam menggunakan metode MICMAC, yaitu di antaranya: (1) identifikasi indikator penentu keberlanjutan, (2) identifikasi hubungan antar indikator, dan (3) pemetaan dan urutan indikator penentu keberlanjutan. Tahap pertama dan kedua dilakukan melalui proses FGD, sedangkan tahap ketiga adalah tahapan pengolahan dan analisis setelah data terkumpul. Pada tahap terakhir ini, data diolah dengan menggunakan software MICMAC.

Berdasarkan Matrix Direct Influence (MDI), masing-masing indikator dalam analisis ini dikelompokkan ke dalam empat kuadran yaitu influence variables, relay variables, depending variables, dan excluded variables. Metode ini adalah cara untuk melihat keberlanjutan dalam jangka pendek. Selanjutnya, untuk melihat bagaimana pengaruh ketergantungan atau keberlanjutan indikator tersebut dalam jangka panjang dapat dilihat pada Matrix Indirect Influence (MII). Melalui matrik ini, dapat diketahui perubahan masing-masing indikator. Selain itu, dengan bantuan MICMAC setiap indikator dapat diurutkan tingkat pengaruh dan ketergantungannya terhadap indikator lain dalam jangka pendek maupun jangka panjang. 


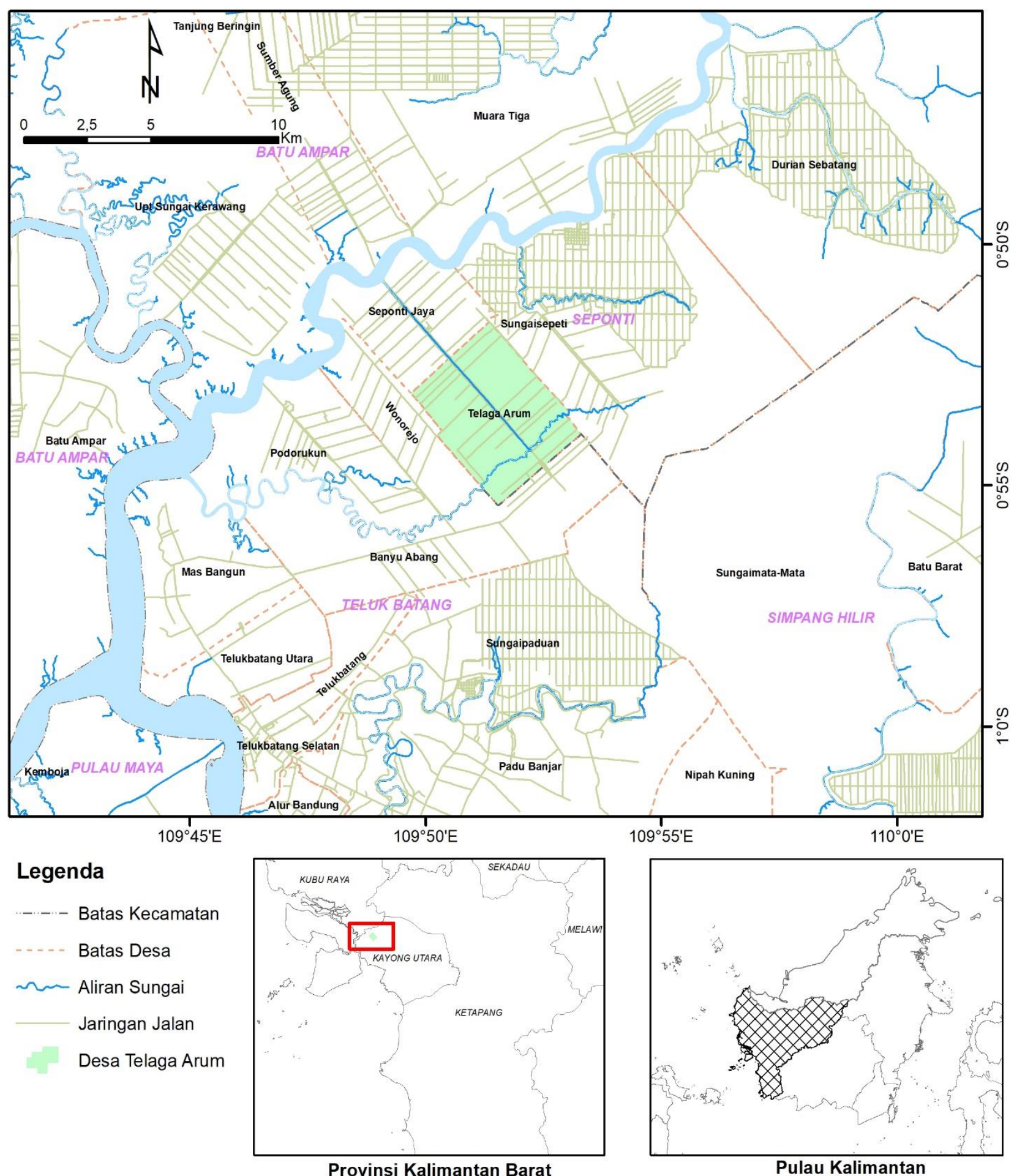

Gambar 1. Peta lokasi penelitian

\section{Hasil dan Pembahasan}

\subsection{Karakteristik Usahatani Padi}

Sebagai dasar memahami faktor-faktor yang menentukan keberlanjutan usahatani padi, perlu diketahui pula karakteristik petani secara umum yang dapat menggambarkan kondisi sosial ekonomi petani.
Kondisi tersebut dapat diketahui berdasarkan umur petani, jumlah anggota keluarga, tingkat pendidikan, pengalaman berusahatani, dan luas lahan usahatani. Selengkapnya karateristik petani dapat dilihat pada Tabel 1. 
Tabel 1. Karakteristik petani di Desa Telaga Arum

\begin{tabular}{|c|c|c|c|}
\hline Variabel & Kategori & Hasil deskriptif & Proporsi (\%) \\
\hline Jumlah sampel & & 33 & \\
\hline \multirow[t]{5}{*}{ Umur petani (tahun) } & $28-37$ & 6 & 18 \\
\hline & $38-47$ & 11 & 33 \\
\hline & $48-57$ & 10 & 30 \\
\hline & $58-67$ & 4 & 12 \\
\hline & $68-78$ & 2 & 6 \\
\hline \multirow[t]{3}{*}{ Jumlah anggota keluarga (orang) } & $1-2$ & 5 & 15 \\
\hline & $3-4$ & 25 & 76 \\
\hline & $5-6$ & 3 & 9 \\
\hline \multirow[t]{5}{*}{ Tingkat pendidikan } & Tidak lulus SD & 11 & 33 \\
\hline & Tamat SD & 17 & 52 \\
\hline & SMP & 2 & 6 \\
\hline & SMA & 2 & 6 \\
\hline & D3/S1 & 1 & 3 \\
\hline \multirow[t]{5}{*}{ Pengalaman usahatani (tahun) } & $1-10$ & 4 & 12 \\
\hline & $11-20$ & 13 & 40 \\
\hline & $21-30$ & 9 & 27 \\
\hline & $31-40$ & 4 & 12 \\
\hline & $41-50$ & 3 & 9 \\
\hline \multirow[t]{5}{*}{ Luas lahan usahatani padi (hektar) } & Tidak punya & 0 & 0 \\
\hline & $<0,5$ & 2 & 6 \\
\hline & $0,5-1$ & 28 & 85 \\
\hline & $1,1-2$ & 3 & 9 \\
\hline & $>2$ & 0 & 0 \\
\hline \multirow[t]{5}{*}{ Luas lahan usahatani karet (hektar) } & Tidak punya & 19 & 57 \\
\hline & $<0,5$ & 4 & 12 \\
\hline & $0,5-1$ & 10 & 30 \\
\hline & $1,1-2$ & 0 & 0 \\
\hline & $>2$ & 0 & 0 \\
\hline \multirow{5}{*}{$\begin{array}{l}\text { Luas lahan usahatani kelapa sawit } \\
\text { (hektar) }\end{array}$} & Tidak punya & 19 & 57 \\
\hline & $<0,5$ & 0 & 0 \\
\hline & $0,5-1$ & 12 & 36 \\
\hline & $1,1-2$ & 2 & 6 \\
\hline & $>2$ & 0 & 0 \\
\hline \multirow[t]{3}{*}{ Produktivitas usahatani padi (ton/ha) } & Terendah & 0,3 & \\
\hline & Tertinggi & 5,4 & \\
\hline & Rata-rata & 1,2 & \\
\hline
\end{tabular}

Sumber: Data primer (2021)

Data pada Tabel 1 memperlihatkan lebih dari 93\% petani yang menanam padi termasuk ke dalam usia produktif, sehingga ini bisa memberi dukungan yang positif terhadap kegiatan usahatani karena akan lebih mudah menerima inovasi (Novita et al., 2016; Kurniati \& Vaulina, 2020). Sebaliknya, jika dilihat dari segi tingkat pendidikannya, dikategorikan masih tergolong rendah, yaitu kurang lebih $85 \%$ tidak lulus atau hanya lulus sekolah dasar. Tingkat pendidikan ini diketahui akan memengaruhi produktivitas usahatani (Reimers \& Klasen, 2013).

Selanjutnya, berdasarkan luas lahannya kurang lebih 91\% petani hanya mengusahakan lahan kurang dari 1 ha hingga 1 ha. Hal ini mengindikasikan usahatani padi di Telaga Arum bukan ditujukan untuk usaha yang komersil. Fakta ini didukung pula oleh kondisi produktivitas padi yang masih tergolong rendah. Padahal, produktivitas padi di lahan rawa pasang surut bisa mencapai 3,5 ton/ha (Suratman, 2020). Hal tersebut dipengaruhi oleh penggunaan input produksi usahatani yang belum optimal.

\subsection{Indikator Penentu Keberlanjutan}

Faktor yang memengaruhi keberlanjutan dalam studi ini digolongkan ke dalam empat dimensi, yaitu ekonomi, ekologi, sosial, dan teknologi. Proses FGD menghasilkan kesepakatan bahwa terdapat 24 indikator yang berhubungan erat dengan keberlanjutan usahatani padi di Telaga Arum (lihat Tabel 2). Awalnya indikator dimaksud berjumlah 27, namun setelah melalui diskusi kemudian disepakati beberapa indikator diabaikan karena dianggap tidak relevan dan beberapa indikator lainnya digabung karena berada dalam ruang lingkup yang sama. 
Tabel 2. Indikator penentu keberlanjutan

\begin{tabular}{|c|c|c|c|}
\hline No & Variabel & Singkatan & Dimensi \\
\hline 1 & Harga gabah & Harga & Ekonomi \\
\hline 2 & Status pemilikan lahan & Skl & Ekonomi \\
\hline 3 & Produksi padi & Produksi & Ekonomi \\
\hline 4 & Harga input & Input & Ekonomi \\
\hline 5 & Luas lahan garapan & Luas & Ekonomi \\
\hline 6 & Kontribusi terhadap pendapatan petani & Ktpp & Ekonomi \\
\hline 7 & Tingkat pendapatan luar usahatani padi* & Splp & Ekonomi \\
\hline 8 & Iklim & Iklim & Ekologi \\
\hline 9 & Penggunaan pupuk & Pupuk & Ekologi \\
\hline 10 & Penggunaan pestisida & Pestisida & Ekologi \\
\hline 11 & Serangan hama dan penyakit tanaman & shpt & Ekologi \\
\hline 12 & Kesuburan tanah & Kesuburan & Ekologi \\
\hline 13 & Kehadiran komoditas kelapa sawit & Kkks & Ekologi \\
\hline 14 & Pendidikan dan keterampilan petani & Pkp & Sosial \\
\hline 15 & Motivasi petani & Motivasi & Sosial \\
\hline 16 & Ketersediaan tenaga kerja keluarga & Ktkk & Sosial \\
\hline 17 & Alternatif usaha selain usahatani padi* & Alternatif & Sosial \\
\hline 18 & Kehadiran penyuluh pertanian & Kpp & Sosial \\
\hline 19 & Keikutsertaan dalam kelompok tani & Kdkt & Sosial \\
\hline 20 & Persepsi petani terhadap konversi lahan & Pptkl & Sosial \\
\hline 21 & Pengolahan tanah & Pengolahan & Teknologi \\
\hline 22 & Penggunaan benih & Benih & Teknologi \\
\hline 23 & Tingkat penerapan teknologi budidaya & Teknologi & Teknologi \\
\hline 24 & Ketersediaan sarana dan prasarana & Sapras & Tekologi \\
\hline
\end{tabular}

Sumber: Data diolah dari hasil FGD

Disamping itu, terdapat pula tambahan satu variabel dalam dimensi ekologi, yaitu variabel kesuburan tanah. Indikator ini dianggap memengaruhi keberlanjutan usahatani padi sawah tadah hujan di Telaga Arum, mengingat kondisi tanah yang memiliki derajat keasaman yang rendah, yaitu pada $\mathrm{pH} 3,5-5,0$. Hal ini yang menyebabkan petani kurang maksimal dalam melakukan pemupukan. Pada tanah yang terlalu asam, maka penyerapan unsur hara oleh tanaman tidak sempurna, sehingga pemupukan sering tidak dapat memberikan hasil yang optimal. Upaya untuk menaikkan $\mathrm{pH}$ tanah dapat dilakukan dengan cara memberikan kapur pertanian, pengolahan tanah yang baik dan tersedianya drainase yang memadai, namun petani belum melakukannya dengan maksimal. Aspek yang harus diketahui bahwa sebagian besar ekologi sawah di Telaga Arum merupakan sawah pasang surut tipe luapan C dan D. Oleh karenanya pH tanah yang rendah cenderung menjadi masalah.

Selain itu, terdapat pula beberapa indikator yang digabung seperti antara alternatif usaha di luar sektor pertanian dan alternatif usaha selain usahatani padi, serta antara aksebilitas menuju lahan pertanian dan ketersediaan sarana dan prasarana. Kemudian, ada beberapa indikator diabaikan seperti permintaan pasar dan budaya gotong royong karena dianggap tidak relevan. Aspek pasar permintaan padi diabaikan karena sebagian besar produksi padi hanya untuk mencukupi kebutuhan sendiri petani dan keluarganya. Sementara itu, budaya gotong royong dalam usahatani padi saat ini sudah mulai ditinggalkan, petani lebih memilih mempekerjakan tenaga kerja keluarga maupun luar keluarga dengan sistem upahan. Ini merupakan bentuk pergeseran baru dalam budaya bertani di Telaga Arum.

\subsection{Penentu Keberlanjutan Usahatani Padi dalam Jangka Pendek}

Untuk memetakan aspek-aspek saling memengaruhi secara langsung dari 24 indikator yang telah disepakati digambarkan dalam bentuk matriks pengaruh langsung (matrix of direct influence) dengan nilai skor 0-3 dan P. Skor 1,2,3 memiliki arti secara berturut-turut sebagai pengaruh kecil, sedang, dan kuat. Skor 0 diberikan ketika pengaruh indikator tersebut terhadap indikator itu sendiri atau ketika tidak ada pengaruhnya secara langsung terhadap indikator lain. Pengaruh langsung dalam bentuk matriks dimaksud, disajikan pada Gambar 2. 


\begin{tabular}{|c|c|c|c|c|c|c|c|c|c|c|c|c|c|c|c|c|c|c|c|c|c|c|c|c|}
\hline & $\begin{array}{l}-\overrightarrow{.} \\
\vec{J} \\
\stackrel{0}{\overrightarrow{0}} \\
0 \\
0\end{array}$ & $\begin{array}{l}N \\
\ddot{o s} \\
\underline{0}\end{array}$ & $\begin{array}{c}\omega \\
\ddot{0} \\
\overline{0} \\
0 \\
0 \\
\frac{0}{c} \\
\hat{\lambda} \\
\underline{\omega} \\
\end{array}$ & 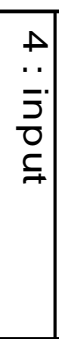 & $\begin{array}{l}c \\
\cdots \\
\vec{c} \\
\vec{c}\end{array}$ & $\begin{array}{l}a \\
\because \\
\bar{\lambda} \\
\bar{\sigma} \\
0\end{array}$ & $\begin{array}{l}v \\
\ddot{s} \\
\frac{0}{0}\end{array}$ & $\begin{array}{c}\infty \\
\ddot{\bar{\lambda}} \\
\overline{\bar{\lambda}} \\
\end{array}$ & $\begin{array}{l}0 \\
\ddot{0} \\
\bar{c} \\
\frac{1}{0} \\
\frac{c}{\lambda}\end{array}$ & 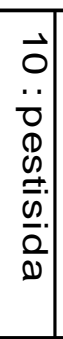 & 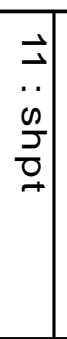 & 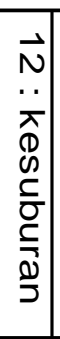 & $\begin{array}{l}\vec{\omega} \\
. \\
\bar{\lambda} \\
\bar{\lambda} \\
\bar{\lambda}\end{array}$ & $\begin{array}{l}\vec{A} \\
\ddot{\partial} \\
\bar{\partial} \\
\overline{0}\end{array}$ & 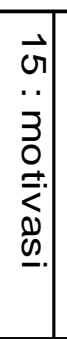 & $\begin{array}{l}\vec{\sigma} \\
\ddot{2} \\
\vec{\lambda} \\
\bar{\lambda} \\
\lambda\end{array}$ & 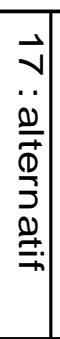 & $\begin{array}{l}\vec{\infty} \\
. \\
\bar{\lambda} \\
0 \\
0\end{array}$ & $\begin{array}{l}\overrightarrow{0} \\
\ddot{\bar{\lambda}} \\
\vec{\lambda} \\
\vec{\lambda}\end{array}$ & & 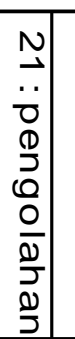 & 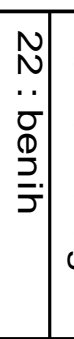 & 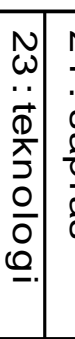 & 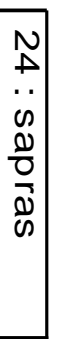 \\
\hline : harga & 0 & 0 & 0 & 0 & 1 & 2 & 0 & 0 & 1 & 1 & 0 & 0 & 1 & 0 & 2 & 0 & 1 & 0 & 0 & 2 & 0 & 2 & 0 & 0 \\
\hline $2: \mathrm{spl}$ & 0 & 0 & 2 & 0 & 2 & 2 & 0 & 0 & 0 & 0 & 0 & 0 & 1 & 0 & 2 & 0 & 2 & 0 & 0 & 1 & 0 & 0 & 0 & 0 \\
\hline 3:produksi & 1 & 0 & 0 & 0 & 0 & 3 & 0 & 0 & 0 & 0 & 0 & 0 & 2 & 0 & 3 & 0 & 3 & 0 & 0 & 3 & 1 & 0 & 0 & 0 \\
\hline 4 : input & 0 & 0 & 0 & 0 & 0 & 3 & 0 & 0 & 2 & 2 & 0 & 0 & 0 & 0 & 1 & 0 & 0 & 0 & 0 & 1 & 2 & 0 & 2 & 0 \\
\hline 5 : Iuas & 0 & 1 & 2 & 0 & 0 & 2 & 1 & 0 & 2 & 2 & 1 & 0 & 0 & 1 & 1 & 1 & 2 & 0 & 0 & 2 & 1 & 2 & 1 & 0 \\
\hline $6: k t p p$ & 0 & 0 & 0 & 0 & 0 & 0 & 0 & 0 & 0 & 0 & 0 & 0 & 0 & 0 & 3 & 2 & 2 & 0 & 0 & 2 & 0 & 0 & 0 & 0 \\
\hline $7: \mathrm{splp}$ & 0 & 0 & 2 & 0 & 3 & 3 & 0 & 0 & 0 & 0 & 0 & 0 & 0 & 2 & 3 & 3 & 0 & 0 & 0 & 3 & 0 & \begin{tabular}{l|l}
0 & 0 \\
\end{tabular} & 0 & 0 \\
\hline 8 : iklim & 0 & 0 & 3 & 0 & 3 & 3 & 0 & 0 & 1 & 3 & 2 & 1 & 1 & 1 & 3 & 0 & 2 & 0 & 0 & 2 & 1 & \begin{tabular}{l|l}
2 & 2 \\
\end{tabular} & 2 & 1 \\
\hline 9 : pupuk & 0 & 0 & 2 & 0 & 0 & 2 & 0 & 0 & 0 & 0 & 1 & 2 & 0 & 1 & 1 & 0 & 0 & 0 & 0 & 2 & 1 & 0 & 2 & 0 \\
\hline 10 : pestisida & 0 & 0 & 3 & 0 & 0 & 3 & 0 & 0 & 0 & 0 & 0 & 2 & 0 & 1 & 2 & 0 & 1 & 0 & 0 & 1 & 2 & 0 & 2 & 0 \\
\hline 11 : shpt & 0 & 2 & 3 & 0 & 1 & 3 & 0 & 0 & 1 & 3 & 0 & 0 & 0 & 1 & 3 & 0 & 2 & 0 & 0 & 2 & 0 & 2 & 2 & 1 \\
\hline 12 : kesuburan & 0 & 2 & 3 & 0 & 2 & 2 & 0 & 0 & 2 & 0 & 0 & 0 & 1 & 2 & 2 & 0 & 2 & 0 & 0 & 3 & 2 & 2 & 2 & 0 \\
\hline $13:$ kkks & 0 & 1 & 3 & 0 & 3 & 3 & 3 & 0 & 1 & 1 & 3 & 2 & 0 & 1 & 3 & 3 & 2 & 1 & 0 & 3 & 1 & 0 & 2 & 1 \\
\hline $14: p k p$ & 0 & 1 & 1 & 0 & 2 & 0 & 2 & 0 & 2 & 2 & 0 & 0 & 0 & 0 & 2 & 2 & 2 & 0 & 0 & 2 & 2 & 2 & 2 & 0 \\
\hline $15:$ motivasi & 0 & 0 & 2 & 0 & 2 & 0 & 0 & 0 & 1 & 1 & 0 & 0 & 0 & 2 & 0 & 3 & 2 & 0 & 1 & 3 & 1 & 0 & 0 & 0 \\
\hline 16 : ktkk & 0 & 0 & 1 & 0 & 2 & 2 & 2 & 0 & 0 & 0 & 0 & 0 & 0 & 0 & 2 & 0 & 2 & 0 & 2 & 0 & 1 & 0 & 1 & 0 \\
\hline $17:$ alternatif & 0 & 1 & 2 & 0 & 2 & 2 & 2 & 0 & 0 & 0 & 3 & 2 & 0 & 2 & 2 & 3 & 0 & 0 & 0 & 3 & 0 & 0 & 0 & 0 \\
\hline $18: \mathrm{kpp}$ & 0 & 0 & 1 & 0 & 1 & 0 & 0 & 0 & 2 & 1 & 0 & 0 & 0 & 2 & 1 & 1 & 2 & 0 & 2 & 1 & 2 & 1 & 2 & 1 \\
\hline $19:$ kdkt & 0 & 0 & 0 & 0 & 1 & 0 & 0 & 0 & 2 & 2 & 0 & 0 & 0 & 2 & 2 & 0 & 1 & 0 & 0 & 1 & 2 & 1 & 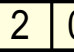 & 0 \\
\hline 20 : pptkl & 0 & 0 & 0 & 0 & 2 & 0 & 0 & 0 & 0 & 0 & 0 & 0 & 0 & 0 & 2 & 0 & 2 & 0 & 0 & 0 & 0 & 0 & \begin{tabular}{l|l}
0 & ( \\
\end{tabular} & 0 \\
\hline 21 :pengolahan & 0 & 0 & 2 & 0 & 0 & 2 & 0 & 0 & 1 & 2 & 0 & 2 & 0 & 2 & 1 & 0 & 0 & 0 & 0 & 0 & 0 & 1 & 2 & 0 \\
\hline 22 : benih & 1 & 0 & 2 & 0 & 0 & 0 & 0 & 0 & 2 & 2 & 2 & 0 & 0 & 2 & 0 & 0 & 0 & 0 & 0 & 0 & 2 & \begin{tabular}{l|l}
0 & 2 \\
\end{tabular} & $2 \mid$ & 0 \\
\hline 23 : teknologi & 0 & 0 & 2 & 0 & 1 & 2 & 0 & 0 & 1 & 2 & 0 & 1 & 0 & 2 & 0 & 0 & 0 & 0 & 0 & 0 & 2 & \begin{tabular}{l|l}
1 & 0 \\
\end{tabular} & \begin{tabular}{l|l}
0 & 1 \\
\end{tabular} & 0 \\
\hline 24 : sapras & 0 & 0 & 2 & 0 & 0 & 2 & 0 & 0 & 0 & 0 & 1 & 0 & 0 & 0 & 2 & 0 & 0 & 0 & 0 & 1 & 0 & \begin{tabular}{l|l}
0 & 0 \\
\end{tabular} & \begin{tabular}{l|l}
0 & $(1$ \\
\end{tabular} & 0 \\
\hline
\end{tabular}

Gambar 2. Matriks pengaruh langsung

Penilaian keseluruhan terhadap matrik Gambar 2 dapat dilihat dari stabilitasnya. Suatu matriks dikatakan baik jika memiliki stabilitas pada kisaran angka 100\%. Oleh karena itu, matriks Gambar 2 dikategorikan memiliki stabilitas yang baik. Hal ini dapat dilihat bahwa setelah melalui 2 kali iterasi didapat stabilitas sebesar 101\% untuk indikator pengaruh dan 99\% indikator ketergantungan (lihat Tabel 3).

Tabel 3. Stabilitas matriks

\begin{tabular}{ccc}
\hline Iteration & Influence & Dependent \\
\hline 1 & $96 \%$ & $99 \%$ \\
2 & $101 \%$ & $99 \%$ \\
\hline
\end{tabular}

Berdasarkan matrix of direct influence pada Gambar 2, masing-masing indikator akan diklasifikasikan ke dalam 4 kuadran dengan tingkat pengaruh dan ketergantungannya yang dinamakan sebagai peta pengaruh langsung (Gambar 3). Pada peta pengaruh langsung tersebut, semakin tinggi tingkat pengaruh suatu indikator maka posisi suatu indikator akan semakin ke atas. Sementara itu, indikator dengan tingkat ketergantungan tertinggi akan berada pada posisi paling kanan. Selanjutnya, ketika indikator berada pada posisi paling bawah, menggambarkan tingkat pengaruh paling rendah jika dibandingkan dengan indikator lainnya, sedangkan ketika indikator berada pada posisi paling kiri, maka berarti memiliki tingkat ketergantungan paling rendah. 


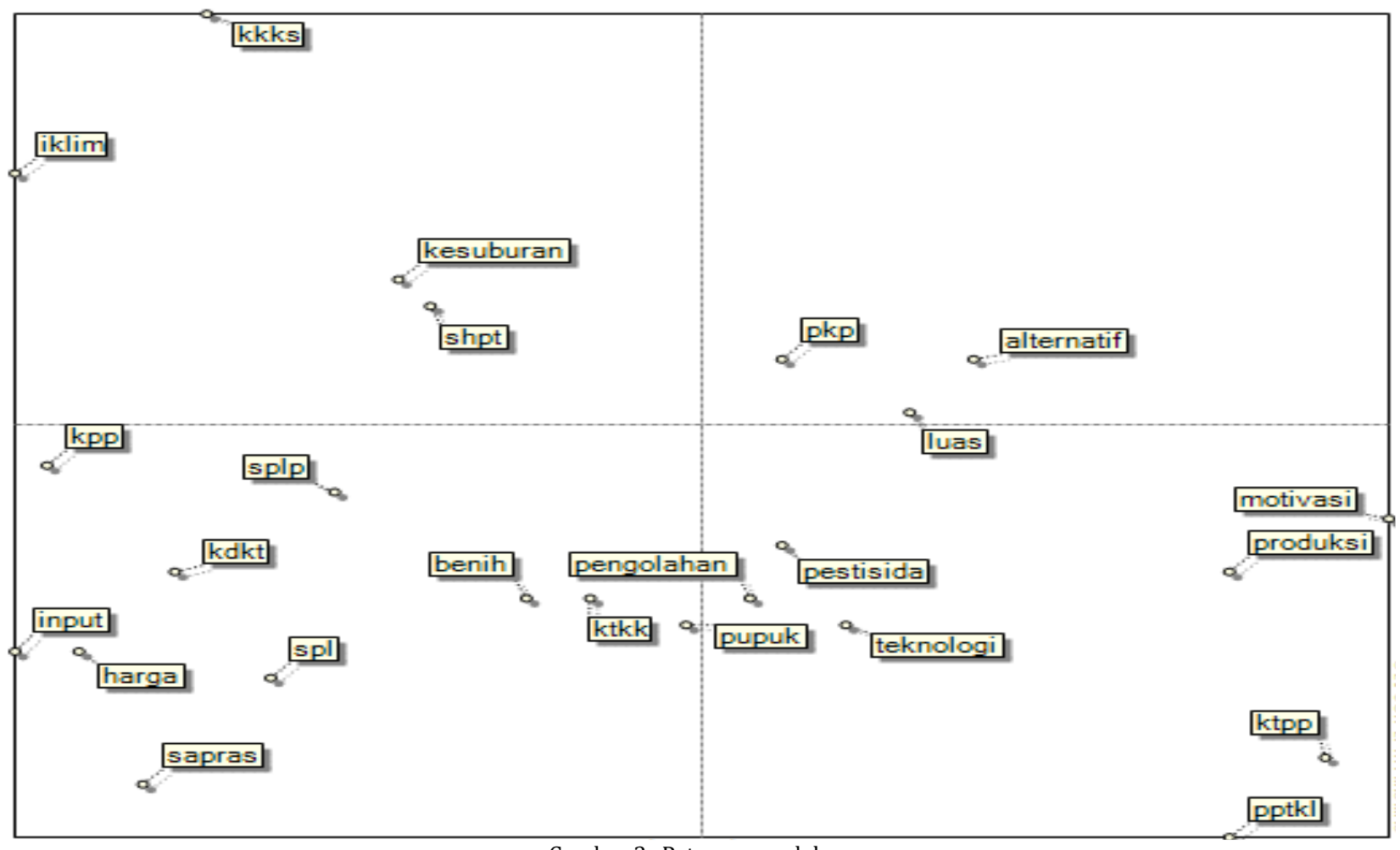

Gambar 3. Peta pengaruh langsung

Berdasarkan Gambar 3 dapat diterangkan empat aspek variabel, yaitu searah jarum jam secara berturutturut terdiri dari influence variables (kuadran I), relay variables (kuadran II), depending variables (kuadran III), dan exclude variables (kuadran IV). Dalam analisis ini, terkait dengan influence variables diperoleh 4 indikator kunci, yaitu kehadiran komoditas kelapa sawit, iklim, kesuburan tanah, dan serangan hama dan penyakit tanaman. Indikator kehadiran komoditas kelapa sawit merupakan aspek dengan tingkat pengaruh paling kuat dalam keseluruhan sistem usahatani padi sawah tadah hujan di Telaga Arum. Perkembangan kebun kelapa sawit swadaya sangat dirasakan dan mulai menggantikan usahatani padi sawah, yaitu dicirikan dengan meningkatnya keputusan konversi pada beberapa petani. Hal ini selaras dengan data BPS (2019), komoditas kelapa sawit di Kabupaten Kayong Utara setiap tahunnya mengalami pertambahan luas, misalnya pada tahun 2017 luasnya hanya sekitar 1.694 hektar, kemudian meningkat menjadi 8.206 hektar pada tahun 2019, atau meningkat kurang lebih 1300 hektar per tahun dalam lima tahun terakhir.

Tekanan akibat kehadiran kelapa sawit dirasakan tidak hanya dari segi lahan, namun juga menimbulkan desakan pada aspek lainnya yang berakumulasi memperkuat terjadinya konversi. Misalnya, penanaman komoditas kelapa sawit yang berdampingan dengan tanaman padi menyebakan populasi tikus semakin meningkat dan bisa menyebabkan lahan kekurangan unsur hara, namun belum banyak petani yang tanggap akan hal ini. Berdasarkan penelitian Dharmayanthi et al. (2018), setiap tanaman kelapa sawit dapat menyerap 12 liter air, sehingga tanaman didekatnya dapat mengalami kekurangan unsur hara dan air.

Pengaruh berikutnya yang juga sangat menentukan adalah indikator iklim. Kondisi iklim yang tidak stabil dapat menyebakan gagal tanam maupun gagal panen. Ruminta (2016) mengemukakan bahwa perubahan iklim dapat mengakibatkan penurunan luas lahan pertanian, penurunan produksi dan produktivitas padi. Kondisi iklim yang berubah-ubah memengaruhi motivasi petani dalam berusahatani padi. Penentu lainnya, juga sangat terasa dipengaruhi oleh kesuburan tanah. Kondisi derajat keasamaan tanah yang kuat sering menyebabkan tanah sawah tadah hujan ini sangat miskin unsur hara. Menurut Asnawi et al. (2020) kesuburan tanah ini selanjutnya dapat memengaruhi ketersediaan air dan produktivitas padi.

Aspek selanjutnya, mengenai serangan hama dan penyakit, dipercaya akan memengaruhi tingkat produksi padi dan akan berdampak pada pendapatan petani. Hal ini selaras dengan hasil penelitian Aji et al. (2014), bahwa akibat adanya serangan hama dan penyakit tanaman berdampak pada terhambatnya perkembangan tanaman padi. Dalam iklim rawa pasang surut yang memiliki tingkat kelembaban tinggi, aspek ini sangat dirasakan oleh para petani di Telaga Arum. Fenomena ini secara umum berbeda dengan hasil penelitian Asnawi et al. (2020) yang menemukan indikator kunci penentu keberlanjutan usahatani padi adalah indikator erosi, kesuburan tanah, dan ketersediaan air. Hal ini dikarenakan jenis sawah yang 
berlainan dan juga berbeda dalam situasi lingkungan alam maupun sosial ekonominya.

Relay variables. Beberapa indikator yang berada pada kuadran ini adalah alternatif usaha selain usahatani padi, luas lahan garapan, serta pendidikan dan keterampilan petani. Indikator yang berada pada kuadran ini menggambarkan ketidakstabilan sistem usahatani padi. Berdasarkan posisinya, indikator alternatif usaha selain usahatani padi merupakan aspek yang memiliki tingkat pengaruh yang kuat. Artinya, semakin banyak jenis usaha yang dapat dilakukan oleh rumah tangga petani, maka semakin tinggi kemungkinan petani beralih profesi. Fenomena ini semakin mengukuhkan bahwa usahatani padi hanya sebagai usaha sampingan yang berorientasi pada pemenuhan kebutuhan subsisten. Selain itu, indikator ini juga memiliki tingkat ketergantungan yang tinggi, terutama karena dipengaruhi oleh rendahnya produktivitas padi. Produktivitas usahatani padi yang tidak maksimal menyebabkan petani harus mencari alternatif usaha lain dalam memenuhi kebutuhan dasar rumah tangganya.

Depending variables. Indikator yang berada pada kuadran ini di antaranya adalah pengolahan lahan, penggunaan pestisida, tingkat penerapan teknologi budidaya, produksi, motivasi petani, kontribusi terhadap pendapatan petani, luas lahan garapan, dan persepsi petani terhadap konversi lahan. Indikator motivasi petani merupakan aspek dengan tingkat ketergantungan tertinggi pada keseluruhan sistem usahatani padi. Motivasi petani dalam berusahatani padi sangat dipengaruhi oleh banyak faktor, seperti jumlah produksi padi, alternatif usaha selain usahatani padi, dan tingkat pendapatan luar usahatani padi. Kebutuhan petani yang sangat beragam jenisnya tidak dapat terpenuhi jika hanya mengandalkan usahatani padi. Posisi indikator ini senada dengan penelitian Barati et al. (2019), bahwa indikator motivasi petani memiliki ketergantungan yang tinggi pada keseluruhan sistem usahatani padi. Oleh karenanya, untuk menumbuhkan motivasi usahatani padi ini harus dimulai dari menumbuhkan ketertarikan dari para petaninya. Selain indikator motivasi petani, produksi padi merupakan indikator dengan tingkat ketergatungan yang tinggi. Hal tersebut disebabkan oleh banyak faktor, satu di antaranya adalah berhubungan erat dengan faktor iklim. Aspek ini sejalan dengan hasil penelitian Ndruru et al. (2014) yang menginformasikan produksi padi sangat dipengaruhi oleh curah hujan, penggunaan pupuk, dan luas panen.

Excluded variables. Indikator yang masuk ke dalam kuadran ini adalah harga input, kehadiran penyuluh pertanian, tingkat pendapatan luar usahatani padi, harga gabah, ketersediaan sarana dan prasarana, keikutsertaan dalam kelompok tani, penggunaan pupuk, ketersediaan tenaga kerja keluarga, penggunaan benih, dan status pemilikan lahan. Indikator harga input memiliki tingkat ketergantungan yang paling rendah pada keseluruhan sistem usahatani padi. Hal ini bermakna bahwa harga input tidak begitu berpengaruh terhadap keputusan petani untuk berusahatani padi, karena faktanya penggunaan input sangat rendah, sebagai konsekuensi dari usahatani padi yang masih berorientasi subsisten.

Analisis selanjutnya terkait bagaimana hubungan tingkat pengaruh-ketergantungan antar indikator keberlanjutan usahatani padi. Secara grafis hubunganhubungan tersebut disajikan pada Gambar 4 .

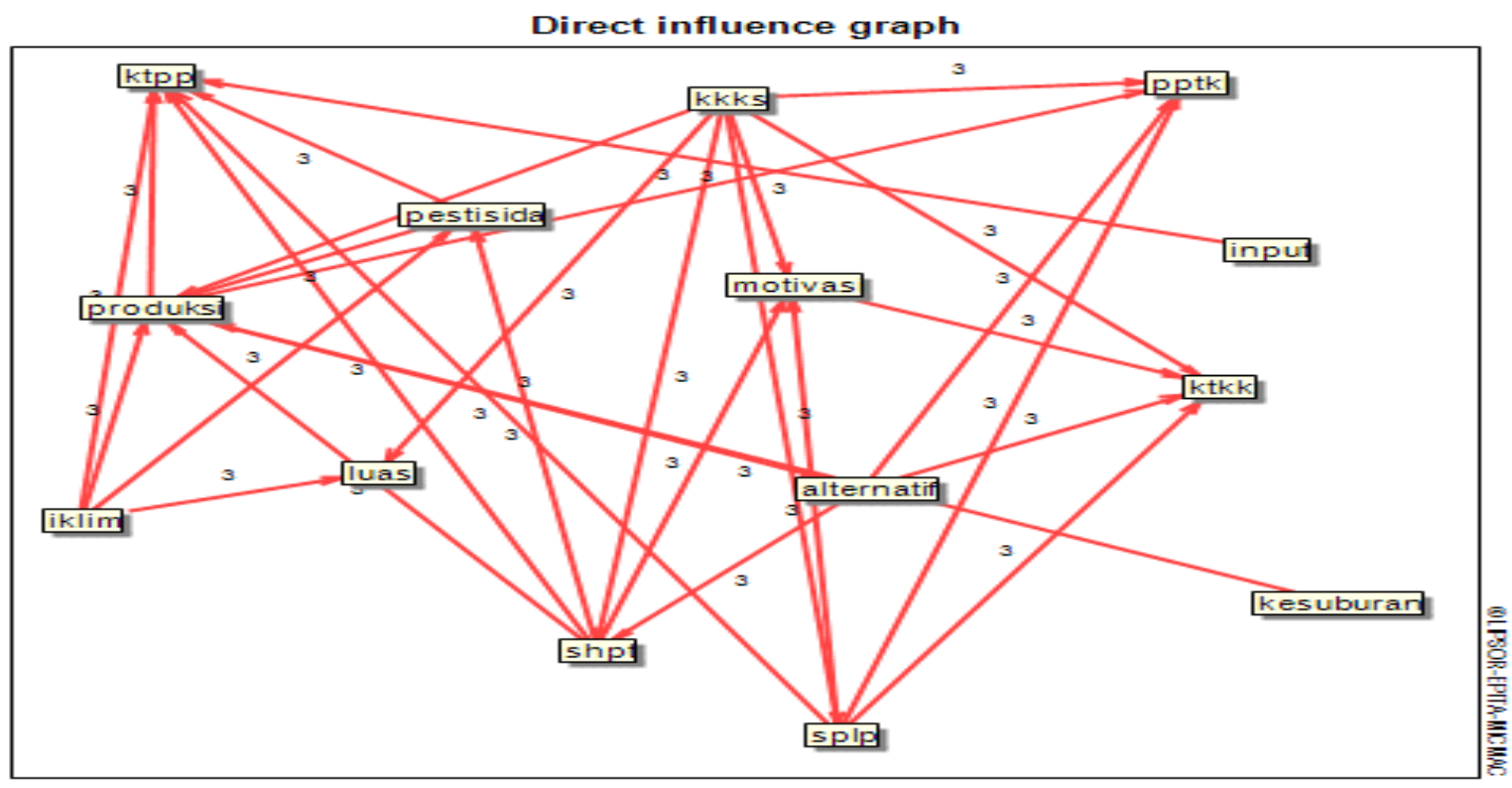

Weakest influences

Weak influences

Moderate influences

Relatively strong influences

Strongest influences

Gambar 4. Grafik pengaruh langsung 
Pada Gambar 4 garis merah tebal menunjukkan bahwa indikator tersebut memiliki pengaruh-ketergatungan yang sangat kuat terhadap indikator lain. Dalam kaitan ini, tampak bahwa kehadiran komoditas kelapa sawit merupakan indikator yang memiliki pengaruh tertinggi. Dalam grafik ditandai dengan jumlah anak panah yang menuju indikator lain sebanyak 7 anak panah, yaitu terhadap indikator luas lahan garapan, produksi padi, serangan hama dan penyakit tanaman, ketersediaan tenaga kerja keluarga, tingkat pendapatan luar usahatani padi, persepsi petani terhadap konversi lahan, dan motivasi petani. Hasil ini menginformasikan bahwa penggunaan lahan untuk kelapa sawit akan semakin meningkat ketika banyak petani yang berhasil. Hal tersebut dikarenakan kebiasaan petani yang cenderung mengikuti petani lain yang berhasil dalam mengembangkan komoditas tertentu. Selain itu, didorong pula oleh motivasi ekonomi berupa keinginan untuk mendapatkan penghasilan yang lebih tinggi. Kondisi ini sejalan dengan temuan Setiawan (2016) bahwa yang mendorong seseorang melakukan konversi lahan adalah karena dipicu oleh desakan kebutuhan hidup sehari-hari yang tidak tercukupi.

Aspek lainnya adalah indikator kontribusi terhadap pendapatan petani. Variabel ini memiliki ketergantungan yang sangat tinggi dengan ditandai oleh 6 anak panah yang menuju indikator tersebut, yakni indikator harga input, penggunaan pestisida, iklim, tingkat pendapatan luar usahatani padi, serangan hama dan penyakit tanaman, dan indikator produksi padi. Artinya bahwa banyak sedikitnya jumlah yang didapat dari usahatani padi sangat bergantung pada indikator-indikator tersebut. Aspek ini selaras dengan temuan Bahruddin (2020) yang menjelaskan bahwa pendapatan yang diperoleh dari usahatani padi sangat dipengaruhi oleh luas lahan garapan, tenaga kerja, penggunaan pestisida, pupuk, dan teknologi pertanian.

\subsection{Penentu Keberlanjutan Usahatani Padi dalam Jangka Panjang}

Melalui bantuan MICMAC, indikator penentu keberlanjutan usahatani padi sawah tadah hujan di Desa Telaga Arum di rangking kembali yang dapat menjelaskan pengaruh tidak langsung. Setiap indikator akan diklasifikasikan kembali ke dalam 4 kuadran. Terdapat beberapa indikator yang mengalami perubahan posisi. Perubahan setiap indikator disajikan pada Gambar 5.

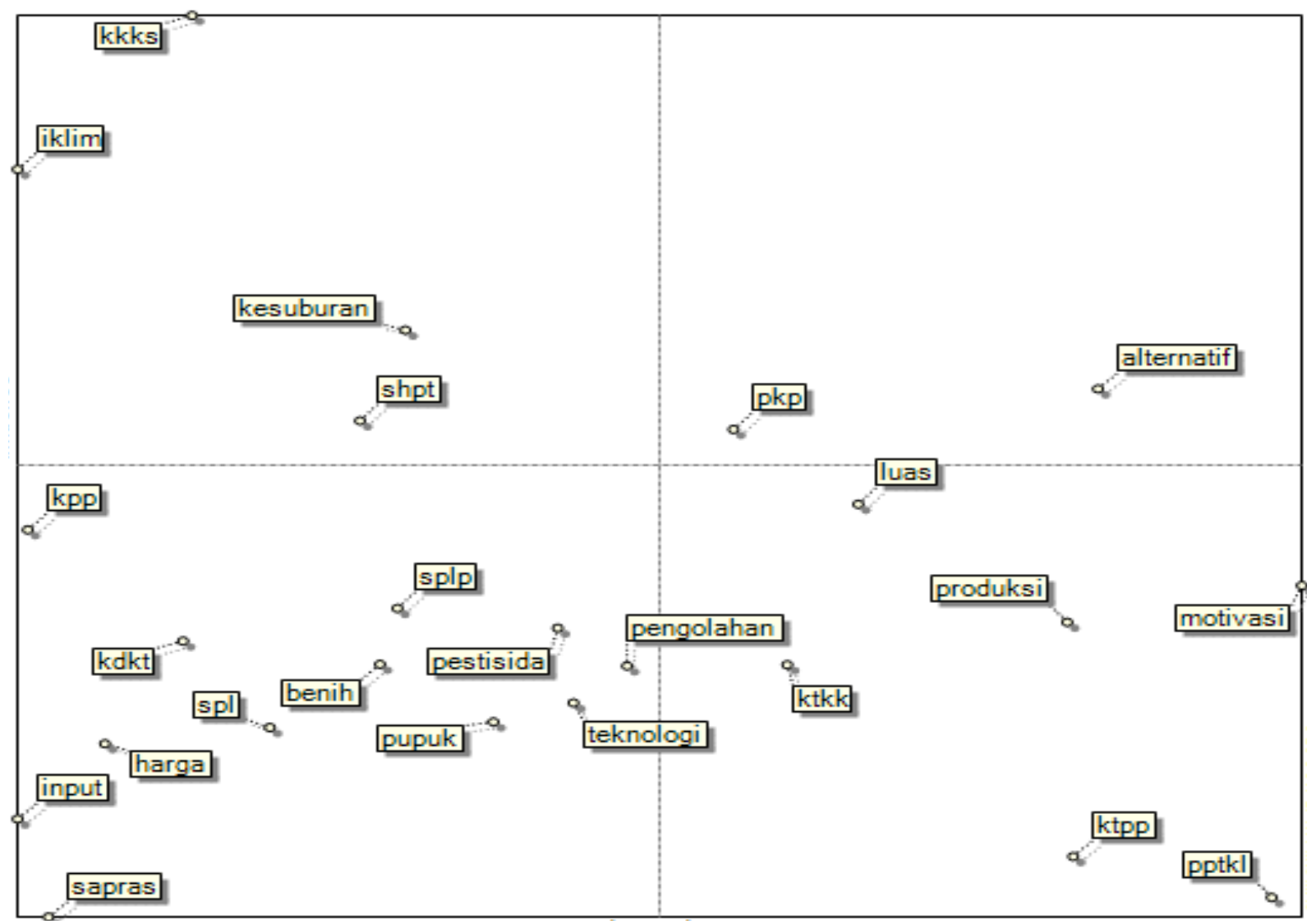

Gambar 5. Peta pengaruh tidak langsung 
Berdasarkan Gambar 5, indikator yang mengalami perubahan posisi yaitu indikator luas lahan garapan dari kuadran relay variables berubah posisi ke kuadran dependent variables. Kemudian indikator penggunaan pestisida, pengolahan lahan, dan tingkat penerapan teknologi berubah dari kuadran depending variables ke kuadran excluded variables. Sebaliknya, indikator ketersediaan tenaga kerja keluarga berpindah posisi dari kuadran excluded variables ke kuadran depending variables. Sementara itu, beberapa indikator hanya berpindah di dalam kuadran masing-masing. Perubahan indikator pada kuadran excluded variables tidak begitu berpengaruh, karena perubahan tersebut tidak sampai memberhentikan sistem usahatani padi.

Berikutnya berdasarkan Gambar 6, angka di setiap panah menunjukkan tingkat derajat pengaruhketergantungan yang diperoleh dari matriks Boolean. Pada grafik pengaruh tidak langsung ini hanya terdapat 2 garis merah tebal, yaitu dari indikator kehadiran komoditas kelapa sawit ke indikator motivasi petani dan juga ke indikator persepsi petani terhadap konversi lahan. Masing-masing garis merah dimaksud memiliki rating paling tinggi yaitu secara berturut turut sebesar 1089 dan 1075 untuk pengaruhnya terhadap motivasi petani dan persepsi petani terhadap konversi lahan. Artinya, dalam jangka panjang kehadiran komoditas kelapa sawit berpengaruh kuat terhadap motivasi petani dan persepsi petani terhadap konversi lahan.

Faktor yang menyebabkan komoditas kelapa sawit mudah diterima oleh petani karena secara ekonomi keuntungan dari budidaya kelapa sawit relatif lebih tinggi, yakni disebabkan biaya pemeliharaan (biaya tenaga kerja) yang relatif rendah. Keuntungan dari rendahnya penggunaan tenaga kerja inilah yang selanjutnya memotivasi para petani untuk terus memperluas kebunnya daripada meningkatkan produktivitas per hektar (Euler et al., 2017). Hal ini pula yang selanjutnya mendorong praktek konversi lahan terjadi secara terus menerus, sehingga pada akhirnya memperburuk kondisi lingkungan hidup. Dilaporkan bahwa persaingan penggunaan lahan antara komoditas kelapa sawit dan padi seperti ini sudah terjadi di beberapa daerah pengembangan kelapa sawit (Susanti \& Burgers, 2013; Zahri et al., 2019).

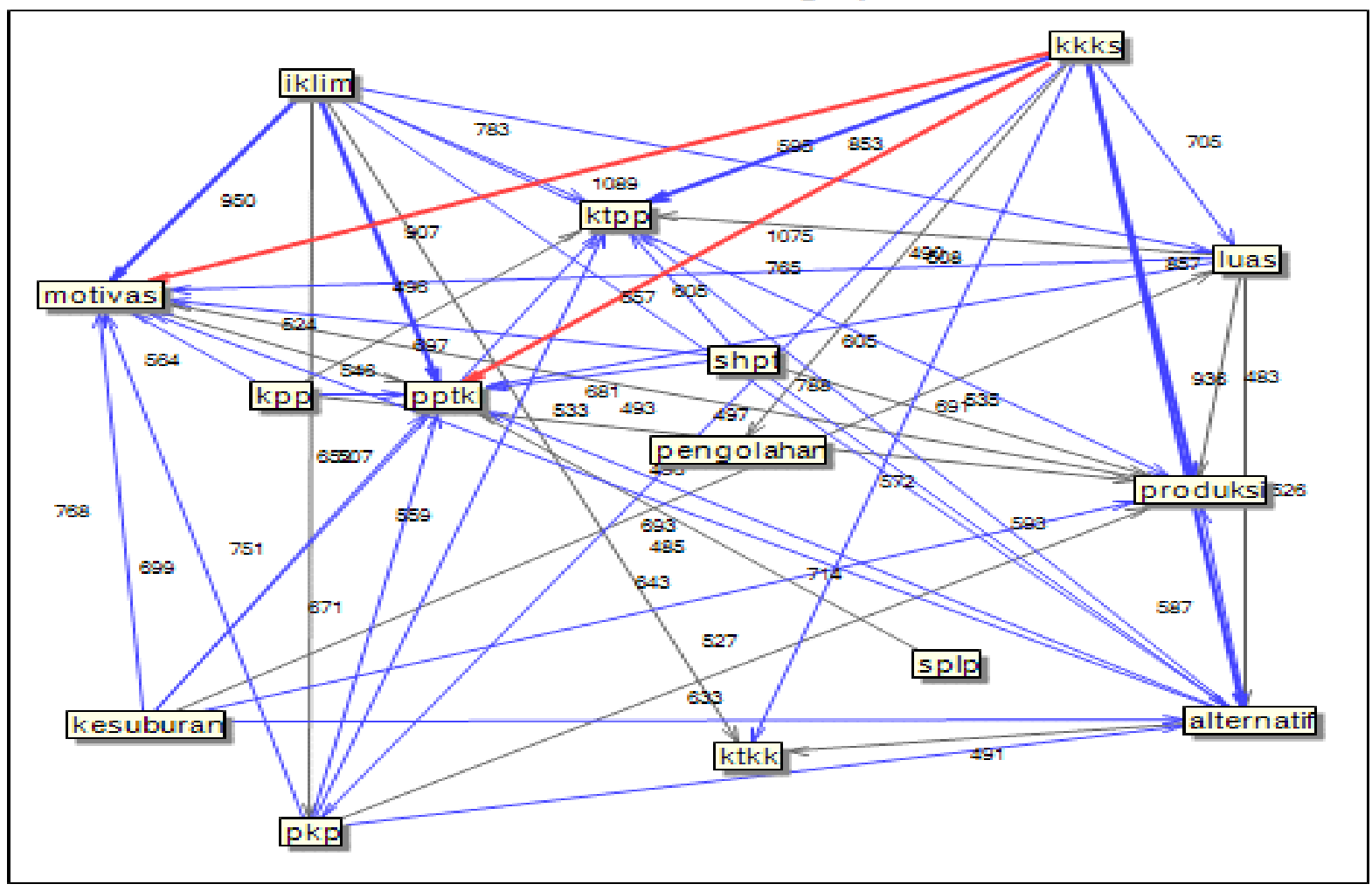

Weakest influences

Weak influences

Moderate influences

Relatively strong influences

Strongest influences

Gambar 6. Grafik pengaruh tidak langsung 


\begin{tabular}{|c|c|c|}
\hline Rank & Variable & Variable \\
\hline 1 & $13-k k k s$ & 13 - kkks \\
\hline 2 & $8-i k \lim$ & $8-i k \lim$ \\
\hline 3 & 12 - kesuburan & 12 - kesuburan \\
\hline 4 & 11 - shpt & 17 - alternatif \\
\hline 5 & $14-\mathrm{pkp}$ & 11 - shpt \\
\hline 6 & 17 - alternatif & $14-p k p$ \\
\hline 7 & 5 - luas & 5 - luas \\
\hline 8 & $18-\mathrm{kpp}$ & $18-\mathrm{kpp}$ \\
\hline 9 & 7 - splp & 15 - motivasi \\
\hline 10 & 15 - motivasi & 7 - splp \\
\hline 11 & 10 - pestisida & 3 - produksi \\
\hline 12 & 3 - produksi & 10 - pestisida \\
\hline 13 & $19-\mathrm{kdkt}$ & $19-\mathrm{kdkt}$ \\
\hline 14 & 16 - ktkk & 22 - benih \\
\hline 15 & 21 - pengolahan & 16 - ktkk \\
\hline 16 & 22 - benih & 21 - pengolahar \\
\hline 17 & 9 - pupuk & 23 - teknologi \\
\hline 18 & 23 - teknologi & 9 - pupuk \\
\hline 19 & 1 - harga & 2 - spl \\
\hline 20 & 4 - input & 1 - harga \\
\hline 21 & $2-\mathrm{spl}$ & 4 - input \\
\hline 22 & 6 - ktpp & 6 - ktpp \\
\hline 23 & 24 - sapras & 20 - pptkl \\
\hline 24 & 20 - pptkl & 24 - sapras \\
\hline
\end{tabular}

Kondisi sebaliknya terjadi pada usahatani padi, yaitu terindikasi semakin meningkatnya ancaman hama dan penyakit tanaman serta dari segi penyediaan sarana produksi sering mengalami kesulitan dalam memperoleh pupuk, sebagaimana hal ini juga dilaporkan oleh Astuti et al. (2011) dan Utami et al. (2017). Perluasan kebun kelapa sawit swadaya ini berkaitan erat dengan hadirnya perusahaan kelapa sawit yang membuka peluang pemasaran tandan buah segar (TBS) di tingkat lokal. Hal inilah yang selanjutnya dirasakan dapat meningkatkan pendapatan petani (Amalia et al., 2019).

Selanjutnya melalui analisis MICMAC dilakukan iterasi Boolean untuk mengetahui perubahan urutan indikator dari Matrix of Direct Influence (MDI) ke Matrix of Indirect Influence (MII). Semakin tinggi urutan indikator maka semakin besar pula pengaruh maupun ketergantungan indikator tersebut. Oleh karena itu, berdasarkan analisis ini indikator dengan ranking tertinggi harus diprioritaskan. Perubahan urutan indikator dari MDI ke MII berdasarkan pengaruhnya disajikan pada Gambar 7.
Berdasarkan Gambar 7, ada 3 indikator yang mengalami perubahan posisi pada MII yang mengacu pada 5 urutan tertinggi, yaitu indikator serangan hama dan penyakit tanaman dan juga indikator pendidikan dan keterampilan petani yang mengalami penurunan dalam jangka panjang, sebaliknya indikator alternatif usaha selain usahatani padi mengalami kenaikan posisi. Hal ini menunjukkan bahwa dalam jangka panjang indikator alternatif usaha selain usahatani padi memiliki tingkat pengaruh yang lebih besar dibandingkan dengan kedua indikator dimaksud. Hasil ini menegaskan bahwa kehadiran komoditas kelapa sawit memiliki pengaruh yang kuat baik dalam jangka pendek maupun jangka panjang, sehingga tidak menutup kemungkinan bahwa pada masa selanjutnya kelapa sawit akan menjadi komoditas utama yang dikembangkan oleh para petani. Penyebab konversi ini menurut Dewi dan Sarjana (2015) disebabkan oleh beberapa aspek, meliputi rendahnya pendapatan usahatani padi, lemahnya kelembagaan, serta lemahnya implementasi rencana detail tata ruang. Selanjutnya, konversi yang tidak terkendali 
menimbulkan dampak lingkungan berupa penurunan keanekaragaman hayati dan debit air saat musim kemarau (Suryadi et al., 2020). Secara sosial ekonomi kehadirannya dilaporkan pula telah menyebabkan kesenjangan pendapatan (Mukti et al., 2014), sehingga hal ini dapat menyebabkan keresahan dan memudarnya norma-norma yang berlaku. Ekspansi kelapa sawit juga dipercaya telah menyebabkan meningkatnya ketidakamanan pangan di perdesaan sebagaimana bukti yang ditunjukkan oleh Sudrajat et al. (2021), bahwa saat ini petani di perdesaan di Kalimantan Barat sudah menggantungkan sebagian kebutuhan pangan pokoknya kepada pasokan dari luar desa.

Analisis ini selanjutnya menunjukkan bahwa faktor iklim dan kesuburan tanah menjadi indikator yang memiliki tingkat pengaruh yang kuat bagi keberlanjutan usahatani padi. Perubahan kondisi iklim dapat menyebabkan tingginya biaya usahatani, misalnya adanya kekeringan seringkali menyebabkan gangguan pertumbuhan tanaman dan meningkatkan biaya penanaman (Ismail, 2017). Kemudian masalah kesuburan tanah sawah di daerah rawa pasang surut umumnya berada pada kondisi yang kurang baik, dan oleh karenanya memerlukan teknologi adaptif dalam mengelolanya. Masalah utama pada jenis tanah ini adalah terkait ketersediaan unsur hara, karena tanah dengan pH 4,5-6,5 termasuk ke dalam tanah yang tidak sehat (Lantoi et al., 2016). Beberapa anjuran untuk memperbaiki sifat kimia dan fisik tanah di Telaga Arum adalah harus dilakukan melalui ameliorasi, di antaranya dengan pemupukan organik, penggunaan dolomit, pupuk kandang, dan kapur pertanian.

Disamping aspek-aspek di atas, pada analisis ini ada indikator yang mengalami kenaikan paling tinggi yaitu, indikator penggunaan benih dan indikator status pemilikan lahan. Selama ini kebanyakan petani masih menggunakan benih padi varietas lokal, mereka menamakannya sebagai padi tahun yaitu jenis Raja Lele dan Ketumbar. Penggunaan padi varietas lokal terkait ini dengan orientasi usahatani yang masih subsisten, sehingga sangat jarang ditemukan petani yang menanam varietas unggul.

Selanjutnya berdasarkan ketergantungannya, indikator penentu keberlanjutan diurutkan kembali untuk melihat tingkat ketergantungan dalam jangka panjang. Selengkapnya, hasil ini disajkan pada Gambar 8.

\begin{tabular}{|c|c|c|}
\hline Rank & Variable & Variable \\
\hline 1 & 15 - motivasi & 15 - motivasi \\
\hline 2 & $6-\mathrm{ktpp}$ & 20 - pptkI \\
\hline 3 & 3 - produksi & 17 - alternatif \\
\hline 4 & 20 - pptkl & $6-\mathrm{ktpp}$ \\
\hline 5 & 17 - alternatif & 3 - produksi \\
\hline 6 & 5 - luas & 5 - luas \\
\hline 7 & 23 - teknologi & 16 - ktkk \\
\hline 8 & 10 - pestisida & $14-p k p$ \\
\hline 9 & $14-\mathrm{pkp}$ & 21 - pengolahan \\
\hline 10 & 21 - pengolahan & 23 - teknologi \\
\hline 11 & 9 - pupuk & 10 - pestisida \\
\hline 12 & $16-$ ktkk & 9 - pupuk \\
\hline 13 & 22 - benih & 12 - kesuburan \\
\hline 14 & 11 - shpt & 7 - splp \\
\hline 15 & 12 - kesuburan & 22 - benih \\
\hline 16 & 7 - splp & 11 - shpt \\
\hline 17 & $2-\mathrm{spl}$ & $2-\mathrm{spl}$ \\
\hline 18 & $13-\mathrm{kkks}$ & $13-\mathrm{kkks}$ \\
\hline 19 & $19-\mathrm{kdkt}$ & $19-\mathrm{kdkt}$ \\
\hline 20 & 24 - sapras & 1 - harga \\
\hline 21 & 1 - harga & 24 - sapras \\
\hline 22 & $18-\mathrm{kpp}$ & $18-\mathrm{kpp}$ \\
\hline 23 & 4 - input & 4 - input \\
\hline 24 & 8 - iklim & 8 - iklim \\
\hline
\end{tabular}

Gambar 8. Perubahan urutan ketergantungan indikator dari MDI ke MII

Berdasarkan Gambar 8, indikator dengan urutan tertinggi pada MDI yaitu motivasi petani, kontribusi terhadap pendapatan petani, produksi, persepsi petani terhadap konversi lahan, dan alternatif usaha selain 
usahatani padi, ternyata hanya indikator motivasi petani yang tidak mengalami perubahan posisi pada 5 urutan tertinggi. Selain itu, informasi yang dapat diperoleh pada Gambar 8 juga menegaskan bahwa dimensi dengan ketergantungan tertinggi baik pada jangka pendek maupun jangka panjang adalah dimensi sosial dan ekonomi.

Melalui analisis ini, motivasi petani dipercaya merupakan indikator yang sangat sensitif. Banyak faktor yang memengaruhi motivasi petani dalam berusahatani padi di Telaga Arum. Menurut Yusuf et al. (2019), kecilnya kontribusi usahatani padi terhadap pendapatan keluarga serta rendahnya peran penyuluh pertanian menyebabkan petani kurang tertarik untuk mengembangkan usahatani padi. Kondisi ini diperkuat oleh hasil penelitian Dzikrillah et al. (2017), bahwa indikator motivasi memiliki sensitivitas tertinggi jika dibandingkan indikator lainnya yang berada pada dimensi sosial budaya. Rendahnya motivasi petani dan tingkat kesadaran mengenai pentingnya usahatani ini, menyebabkan usahatani padi sawah kurang berkembang.

Sementara itu, indikator ketersediaan tenaga kerja keluarga mengalami peningkatan posisi yang signifikan dalam MII, dari urutan 12 menjadi urutan ke 7. Selama ini tenaga kerja keluarga yang banyak terlibat dalam berusahatani padi hanya suami dan istri saja, sedangkan tenaga kerja anak hanya pada kegiatan tertentu, seperti penanaman. Kondisi ini sejalan dengan temuan Linda et al. (2018) bahwa sebagian besar kegiatan usahatani padi hanya dilakukan oleh kepala keluarga, sedangkan anggota keluarga lainnya lebih memilih pekerjaan lain di luar usahatani padi, sehingga dalam hal ini ada fenomena pula bahwa usahatani padi semakin tidak menarik bagi generasi muda.

\section{Kesimpulan}

Keberlanjutan usahatani padi sawah tadah hujan di Telaga Arum ditentukan oleh 24 indikator yang dapat dikelompokkan ke dalam empat dimensi, yaitu dimensi ekonomi, ekologi, sosial, dan teknologi. Keberlanjutan usahatani padi sawah tadah hujan di daerah pesisir ini sangat ditentukan oleh dimensi ekologi, yaitu di antaranya adalah indikator kehadiran komoditas kelapa sawit, indikator iklim, dan indikator kesuburan tanah. Ketiga indikator tersebut dapat menyebabkan terganggunya sistem usahatani padi sawah, bukan hanya dalam jangka pendek namun juga jangka panjang. Memahami ketiga indikator itu, kehadiran kebun kelapa sawit swadaya merupakan aspek yang perlu mendapat perhatian, karena tekanan dari kehadirannya ini bersifat masif sehingga sangat berpeluang menimbulkan kelangkaan lahan untuk pengembangan komoditas pangan di perdesaan. Lebih jauh, dalam jangka panjang, indikator yang paling sensitif memengaruhi keberlanjutan usahatani padi adalah aspek motivasi petani. Segi motivasi petani ini akan cenderung mengalami kemunduran sepanjang usahatani padi tidak bisa memberi insentif yang memadai bagi petani. Oleh karena itu, penerapan teknologi yang adaptif dengan sumber daya alam lokal merupakan aspek yang sangat diperlukan dalam meningkatkan produktivitas usahatani padi sawah tadah hujan di wilayah pesisir Kalimantan Barat.

\section{DAFTAR PUSTAKA}

Aji, A. A., Satria, A., \& Hariono, B. (2014). Strategi Pengembangan Agribisnis Komoditas Padi dalam Meningkatkan Ketahanan Pangan Kabupaten Jember. Jurnal Manajemen \& Agribisnis, 11(1), 60-67.

Amalia, R., Dharmawan, A. H., Prasetyo, L. B., \& Pacheco, P. (2019). Perubahan Tutupan Lahan Akibat Ekspansi Perkebunan Kelapa Sawit: Dampak Sosial, Ekonomi, dan Ekologi. Jurnal Ilmu Lingkungan, 17(1), 130-139. https://doi.org/10.14710/jil.17.1.130-139

Asnawi, R., Arifin, B., Zakaria, W.A., Banua, I. S., \& Abidin, Z. (2020). Analysis of Key Variable for Rice Farming Sustainability in the Downstream of Sekampung Watershed: An Application of MICMAC Method. Journal Plant Archives, 20(2), 7895-7904.

Astuti, U. P., Wibawa, W., \& Ishak, A. (2011). Faktor yang Memengaruhi Alih Fungsi Lahan Pangan Menjadi Kelapa Sawit di Bengkulu: Kasus Petani di Desa Kungkai Baru. Prosiding Seminar Nasional Budidaya Pertanian / Urgensi dan Strategi Pengendalian Alih Fungsi Lahan Pertanian, 189-195.

Bahruddin. (2020). Analisis Faktor-Faktor yang Memengaruhi Pendapatan Petani Padi di Kecamatan Patampanua Kabupaten Pinrang. Jurnal Ekonomi dan Bisnis, 3(1), 17-28.

Barati, A. A., Azadi, H., Pour, M. D., Lebailly, P., \& Qafori, M. (2019). Determining Key Agricultural Strategic Factors Using AHP-MICMAC. Journal Sustainability, 11(14), 117. https://doi.org/10.3390/su11143947

BPS. (2019). Luas Tanaman Perkebunan Rakyat 2017-2019. Kabupaten Kayong Utara: BPS.

Dewi, I. A. L., \& Sarjana, I. (2015). Faktor-faktor Pendorong Alih Fungsi Lahan Sawah Menjadi Lahan Non Pertanian. Jurnal Manajemen Agribisnis, 3(2), 163-171.

Dharmayanthi, E., Zulkarnaini, \& Sujianto. (2018). Dampak Alih Fungsi Lahan Pertanian Menjadi Perkebunan Kelapa Sawit terhadap Lingkungan, Ekonomi, dan Sosial Budaya di Desa Jatibaru Kecamatan Bunga Raya Kabupaten Siak. Dinamika Lingkungan Indonesia, 5(1), 34-39.

Dzikrillah, G. F., Anwar, S., \& Sutjahjo, S. H. (2017). Analisis Keberlanjutan Usahatani Padi Sawah di Kecamatan Soreang Kabupaten Bandung. Jurnal Pengelolaan Sumberdaya Alam dan Lingkungan, 7(2), 107-113. https://doi.org/10.29244/jpsl.7.2.107-113

Euler, M., Krishna, V., Schwarze, S., Siregar, H., \& Qaim, M. (2017). Oil Palm Adoption, Household Welfare, and Nutrition among Smallholder Farmers in Indonesia. World Development, 93, 219-235. https://doi.org/10.1016/j.worlddev.2016.12.019

Fauzi, A. (2019). Teknik Analisis Keberlanjutan (1st ed.). Jakarta: PT Gramedia Pustaka Utama.

Ismail, U. P. (2017). Dampak Teknis dan Ekonomis Perubahan Iklim pada Pengolahan Tanah Sawah Tadah Hujan di Kabupaten Kampar Provinsi Riau. Seminar Nasional 
"Mitigasi dan Strategi Adaptasi Dampak Perubahan Iklim di Indonesia, 1-3.

Kurniati, S. A., \& Vaulina, S. (2020). Pengaruh Karakteristik Petani dan Kompetensi terhadap Kinerja Petani Padi Sawah di Kecamatan Gunung Toar Kabupaten Kuantan Singingi. Jurnal Agribisnis, 22(1), 1-16.

Lantoi, R. R., Darman, S., \& Patadungan, Y. S. (2016). Identifikasi Kualitas Tanah Sawah pada Beberapa Lokasi di Lembah Palu dengan Metode Skoring Lowery. Jurnal Agroland, 23(3), 243-250.

Linda, A. M., Ambarawati, I., \& Ustriyana, I. N. G. (2018). Status Keberlanjutan Usahatani Padi Sawah di Kota Denpasar (Studi Kasus Subak Intaran Barat, Desa Sanur Kauh , Kecamatan Denpasar Selatan). Jurnal Managemen Agribisnis, 6(1), 55-62.

Mukti, A., Setiawan. B., Pramoedyo, H., \& Fatah, L. (2014). The Impact of Palm Oil Plantation Development towards Income Disparity. Academic Research International, 5(2), 96-106.

Ndruru, R. A., Situmorang, M., \& Tarigan, G. (2014). Analisa Faktor-faktor yang Memengaruhi Hasil Produksi Padi di Deli Serdang. Saintia Matematika, 2(1), 71-83.

Noor, M., Nursyamsi, D., Alwi, M., \& Fahmi, A. 2014. Propspek Pertanian Berkelanjutan di Lahan Gambut: Dari Petani ke Peneliti dan Peneliti ke Petani. Jurnal Sumberdaya Lahan, 8(2), 69-79.

Novita, S., Denmar, D., \& Suratmo, T. (2016). Hubungan Karakteistik Sosial Ekonomi Petani dengan Tingkat Penerapan Teknologi Usahatani Padi Sawah Lahan Rawa di Kecamatan Sekernan Kabupaten Muaro Jambi. Jurnal Sosio Ekonomika Bisnis, 19(1), 1-12.

Reimers, M. \& Klasen, S. (2013). Revisiting the Role of Education for Agricultural Productivity. American Journal of Agricultural Economics, 95(1), 131-152. http://dx.doi.org/10.1093/ajae/aas118

Ruminta. (2016). Analisis Penurunan Produksi Tanaman Padi Akibat Perubahan Iklim di Kabupaten Bandung Jawa Barat. Jurnal Kultivasi, 15(1), 37-45.

Setiawan, H. P. (2016). Alih Fungsi (Konversi) Lahan Pertanian Ke Non Pertanian Kasus di Kelurahan Simpang Pasir Kecamatan Palaran Kota Samarinda. EJournal Sosiatri-Sosiologi, 4(2), 280-293.
Sudalmi, E. S. (2010). Pembangunan Pertanian Berkelanjutan. Jurnal Inovasi Pertanian, 9(2), 15-28.

Sudrajat, J., Suyatno, A., \& Oktoriana, S. (2021). Land-Use Changes and Food Insecurity around Oil Palm Plantations: Evidence of the Village Level. Forest and Society, 5(2), 352-364. https://doi.org/10.24259/fs.v5i2.11376

Suratman, Y. Y. A. (2020). Produktivitas dan Pendapatan Usahatani Padi Sawah Tadah Hujan di Kelurahan Cempaka Kota Banjarbaru. Jurnal Sains STIPER Amuntai, 10(2), 87-94. http://doi.org/10.36589/rs.v10i2.136

Suryadi, Dharmawan, A. H., \& Barus, B. (2020). Ekspansi Perkebunan Kelapa Sawit: Persoalan Sosial, Ekonomi dan Lingkungan (Studi Kasus Kab. Pelalawan, Riau). Jurnal Ilmu Lingkungan, 18(2), 367-374. https://doi.org/10.14710/Jil.18.2.367-374

Susanti, A. \& Burgers, P. (2013). Oil Palm Expansion: Competing Claim of Lands for Food, Biofuels, and Conservation. In Behnassi et al. (Eds.), Sustainable Food Security in the Era of Local and Global Environmental Change (301-320). Dordrecht, Netherland: Springer. doi:10.1007/978-94-007-6719-5_19

Utami, R., Putri, E. I. K., \& Ekayani, M. (2017). Dampak Ekonomi dan Lingkungan Ekspansi Perkebunan Kelapa Sawit (Studi Kasus: Desa Penyabungan, Kecamatan Merlung, Kabupaten Tanjung Jabung Barat, Jambi ). Jurnal Ilmu Pertanian Indonesia, 22(2), 115-126. https://doi.org/10.18343/jipi.22.2.115

Widians, J., \& Rizkyani, F. N. (2020). Identifikasi Hama Kelapa Sawit menggunakan Metode Certainty Factor. ILKOM Jurnal Ilmiah, 12(1), 58-63.

Yusuf, R., Pato, U., Tang, U. M., \& Karnila, R. (2019). Analisis Keberlanjutan Dimensi Sosial Budaya Usahatani Padi Sawah di Kabupaten Siak Provinsi Riau. Dinamika Lingkungan Indonesia, 6(2), 85 https://doi.org/10.31258/dli.6.2.p.85-94

Zahri, I., Wildayana, E., Ak, A.T., Adriani, D., \& Harun, M.U. (2019). Impact of conversion from rice farms to oil palm plantations on socio-economic aspects of ex-migrants in Indonesia. Agricultural Economics, 65(12), 579-586. https://doi.org/10.17221/349/2018-AGRICECON. 